\title{
The role of financial technology to increase financial inclusion in Indonesia
}

\section{Florentina Kurniasari $^{a^{*}}$, Ardi Gunardi ${ }^{\mathrm{b}}$, Farica Perdana Putri ${ }^{\mathrm{c}}$ and Andy Firmansyah ${ }^{\mathrm{a}}$}

\author{
${ }^{a}$ Technology Management Department, Universitas Multimedia Nusantara, Tangerang, Indonesia \\ ${ }^{b}$ Faculty of Economics and Business, Universitas Pasundan, Bandung, Indonesia \\ 'Information Technology Department Universitas Multimedia Nusantara, Tangerang, Indonesia

\section{H R O N I C L E}

Article history:

Received: March 21, 202

Received in revised format: April

25,2021

Accepted: May 3, 2021

Available online: May 3, 2021

Keywords:

Financial Inclusivity

Financial Service Facilities

Regulatory Services

Social Networking

Customer Knowledge

Customer Decision

\section{Introduction}

As the world advances rapidly, digital technology continues to develop. Considered one of the emerging countries in the world, Indonesia also faces the growth of digital technology innovation. Indonesia has a population reaching 265.4 million, with more than 143.2 million people as active users of the internet and 130 million of these with social media accounts (World Bank Report, 2018). The Indonesian government has launched an e-commerce roadmap with the aim of creating a new 1.000 startup business with a market valuation of US $\$ 10$ billion and the value of the e-commerce reaching US $\$ 130$ billion by the end of 2020. The policy initiated some strategy in developing information technology across the nation through the utilization of financial technologies, Internet of Things (IOT), as well as the utilization of higher market share in the field of information and communications technology (ICT) on-demand services (Kementerian Informasi dan Komunikasi, 2018). In 2018, the financial technology businesses grew at $24.6 \%$ annually with the total market transaction value reaching US $\$ 22.338$ million (Kementerian Informasi dan Komunikasi, 2018). The government was also committed in developing the national fiber optic infrastructure (was called Palapa Ring) to provide the availability of communication services. This project would give more affordable communication services, accelerate development in the Eastern region of Indonesia, as well as support the implementation of electronic application and increase prosperity for all including more access for financial inclusion through the utilization of financial technologies (Kementerian Informasi dan Komunikasi, 2018). Although the rate of economic growth and consumption in Indonesia reached $5.8 \%$ in 2017 , the level of financial literacy of the community was low. Only $48.9 \%$ of its people had access to banks, and only $23 \%$ of them were using financial technology in conducting their financial transactions. Ultramicro segments, considered the backbone of the economy contributing 59\% to GDP and 97\% of the country's labor

* Corresponding author.

E-mail address: florentina@umn.ac.id (F. Kurniasari)

(C) 2021 by the authors; licensee Growing Science, Canada. doi: $10.5267 /$ j.ijdns.2021.5.004 
absorption, experienced difficulties in accessing financial institutions. Fifty-nine percent of them had limited access to the banking system, and only $26 \%$ were able to utilize credit loans from banks to develop their businesses. Financial institutions in Indonesia were able to distribute loans as much as 148 trillion rupiahs in 2017, mostly for big corporations (Herdiawan, 2017). To support the growth of businesses, the government provided regulations to encourage the ultramicro segment to get business loans from financial technology companies, especially from the Peer-to-Peer (P2P) lending in Indonesia (Bank Indonesia FinTech Office, 2017). This new platform was expected to encourage the growth of the digital economy while simultaneously exposing the public to financial services (financial inclusion). The island of Java has recorded the highest loan growth rate, especially in Central Java. This is expected since more than $50 \%$ of the ultramicro segment markets are locally concentrated in Java. Currently, the majority of small-medium enterprises (SMEs) are served financially by conventional rural banks. Indonesia has 1,726 rural banks; $62 \%$ of them are located in Java Island and serve 12.5 million customers. Only $0.4 \%$ of these have mobile money accounts, and $11.2 \%$ do online financial transactions (IBRD/The World Bank, 2018). Table 1 shows the number of financial transactions conducted by rural banks (nationally) for four consecutive years.

Table 1

Rural Banks Financial Transaction

\begin{tabular}{cccc}
\hline $\begin{array}{c}\text { Year } \\
\text { (as per 31 December) }\end{array}$ & Number of Customers & $\begin{array}{c}\text { Amount Third Party Fund } \\
\text { (in trillion rupiahs) }\end{array}$ & $\begin{array}{c}\text { Amount Credit Distribution } \\
\text { (in trillion rupiahs) }\end{array}$ \\
\hline 2014 & 13 Million & 86 & 68 \\
2015 & 13 Million & 83 & 74 \\
2016 & 14 Million & 90 & 80 \\
2017 & 12.5 Million & 88 & 79 \\
\hline
\end{tabular}

Source: Bank Indonesia Report (2018).

From the above table, an $18 \%$ decline in the credit distribution amount can be observed in 2017 . This is the result of an increase in number of loans offered by P2P lending and infrastructure gaps (Bank Indonesia Report, 2017). The SMEs' decision in using financial technology was strongly influenced by their knowledge and familiarity of the new financial platform. Therefore, the objective of the research was to analyze the role of digital technology to increase customer decision in using financial technology (herein termed fintech) services by using customer knowledge as an intervening variable.

\section{Literature Review}

Accenture's (2016) research showed that global investment was growing rapidly, around 67\% per year, in the Asia-Pacific region, in which Indonesia had the highest position. Digital technology advancements changed the business model and how companies could create value by utilizing the internet (Hartman et al., 2000). The digital economy had several characteristics, such as the growth of the internet, the rise of innovation, and globalization, that would change the current economic system in various industries such as finance and banking. Information technology transformed social interaction and personal relationships by taking advantage of ICT advancement (OECD, 2017). Fintech is a new business model that combines financial services and technology. Its growth changed the current conventional banking system. It is a financial business innovation encouraged by the rise of the sharing economy system, the relaxation of government regulation, and the advancement of information technology (Bank Indonesia Report, 2018). Fintech brings more advantages to customers, the government, and related industries. It provides a variety of product options for customers, along with better quality in affordable prices. Fintech also supports the government by contributing to the development of the nation, reducing unemployment, increasing welfare, and strengthening the economic system (Lee \& Shin, 2018). It became a business opportunity to shorten the transaction chain, increase the efficiency, support the financial inclusion, and create smooth information exchange flow (Herdiawan, 2017). Financial inclusivity is a condition where affordable financial products and services, delivered in a responsible and sustainable way, are available for people to meet their needs. It gives equal opportunities for people, especially those unbanked and underbanked, to get better access into financial services (Nanda \& Kaur, 2016). It aims to provide people with reasonable access at a reasonable cost to comprehensive financial services, including savings or investment services, payment, and credit services. These financial activities are governed by regulations to protect the consumers and ensure healthy competition in industries. Financial inclusion is expected to reduce poverty and boost shared prosperity among people in Indonesia (World Bank Report, 2018).

Crowdfunding or P2P lending is an alternative new business model of fintech that provides services, such as fund collection and lending, with the use of technology (Blohm, Leimester, \& Kremar, 2013). To better understand the competition and the dynamics of fintech industry, the fintech ecosystem needs to be studied (Bank Indonesia Report, 2018). Diemers, Lamaa, Salamat, and Steffens (2015) explained five major elements of the fintech ecosystem: fintech startup, technology developers, government, customers, and other traditional financial institutions such as banks, insurance, and others. Fintech startup refers to any financial startups that provide financial services such as lending (P2P lending). These new platforms offer unbundling financial services that are not offered by conventional banks (Walchek, 2015). P2P lending brought more options to individuals or corporations to give or receive lending activities from one another with the use of the internet. The platform offered more simple and speedy lending solutions with lower interest rates. One significant difference between financial startups and banks was the involvement in the process, as P2P lending startups are not directly involved in the lending process and only acted as intermediaries that connect fund owners (lenders) to borrowers. They provide the ICT infrastructure to support the 
transaction. Transaction fees are collected from both lenders and borrowers (Bank Indonesia Report, 2018). While large capital is not required like banks, P2P lending startups ensure that all financial transactions done in their platform are safe and are based on formal and proper regulations to protect the interest of all parties (Williams-Grut, 2016). The lending process begins by analyzing sources of information carefully, accelerating the lending process, simplifying the administration process, and setting up maximum nominal lending amount and repayment period (Zhu, Dholakaia, Chen, \& Algesheimer, 2012). The success of the P2P lending depends on their strategy for risk mitigation. Technology developers refer to internet provider companies that provide cloud computing, social media developers, and big data analysis. Appropriate technology infrastructure enables customers to access financial transactions anytime and everywhere (Reuters, 2016). The government, as part of the fintech ecosystem, established clear financial regulation related to capital adequacy requirements, customer protection, and tax incentives (Holland FinTech, 2015). In the new financial platforms, establishing proper financial policies by the government will likely minimize possible risks related to technology innovation (Herdiawan, 2017). In addition, the relaxation of government regulation encouraged more P2P lending startups to give more personalized services at more affordable prices and easier access (Bank Indonesia Report, 2018).

Another part of the fintech ecosystem, customers, refers to all parties (individual or institution) that use fintech in doing their financial transactions. The main customers of P2P lending are those who had good prospects of their businesses but had limited access to borrow funds from conventional banks. Holland FinTech (2015) showed that the majority of P2P lending customers are SMEs and the millennial generation who are active users of internet and social media. With the size of their business and the limited capital to expand, SMEs were the main target of P2P lending. In addition, their limited assets as collateral provided SMEs with difficulties in borrowing funds from banks. Traditional financial institutions such as banks, insurance, or leasing companies and pawnshop also influence the fintech ecosystem. Banks, with bigger financial resources, had more advantages in terms of their capabilities to achieve the economies of scales. Since banks could only serve comprehensive bundling products to the customers, the existence of P2P lending became a serious threat for these institutions (Yang, 2015). Social networking played an important role in the success of this new business platform (Zvilichovsky et al., 2013). The social networking theory focuses on the importance of social relationships for information transmission that encourages the change in people's behavior. Kuppuswamy and Bayus (2013) explained the significant effect of families and friends in financial decisions, as families and friends gave more information and recommendation regarding the trusted fintech. Understanding the fintech ecosystem would give more adequate information for customers of new platforms before making decisions in choosing the P2P lending for their financial transactions (Khosravi, 2014; Uddin, Lopa, \& Oheduzzaman, 2014). As customers rely on P2P lending to get more information about the platform, P2P lending startups had to develop good communication channels to share all related information (Tseng, Shu-Mei, \& Pin-Hong Wu, 2014). Salomann, Dous, Kolbe, and Brenner (2005) stated that customer knowledge is categorized into three dimensions (Khodakarami \& Chan, 2014), namely knowledge for customers (all available information provided for the customers), knowledge about customers, and knowledge from customers (all available information provided by customers as source of innovation). The more information the customers could access, the better it assists them in making sound financial decisions (Nguyen \& Harrison, 2018; Kurniasari, Jusuf, \& Gunardi, 2018). As customers seek plenty of information related to the P2P lending from trusted sources such as family and friends, various communication elements and interaction behavior could influence their decisions, such as trust, satisfaction, and clear information (Anothai \& Beise-Zee, 2014; Gaur, Xu, Quazi, \& Nandi, 2011). This exchange will develop interaction and build long-term relationships (Tai \& Ho, 2010). Egbunike, Emudainohwo, Gunardi, Kurniasari, and Prihanto (2018) stated that social interaction is an important media for information exchange. With the available information, customers will likely have a thorough understanding of the fintech ecosystem and will assist them in choosing the P2P lending startup to do transactions with (Khosravi, 2014; Uddin et al., 2014). A theoretical framework is developed from the literature review studied, as can be seen in Fig. 1.

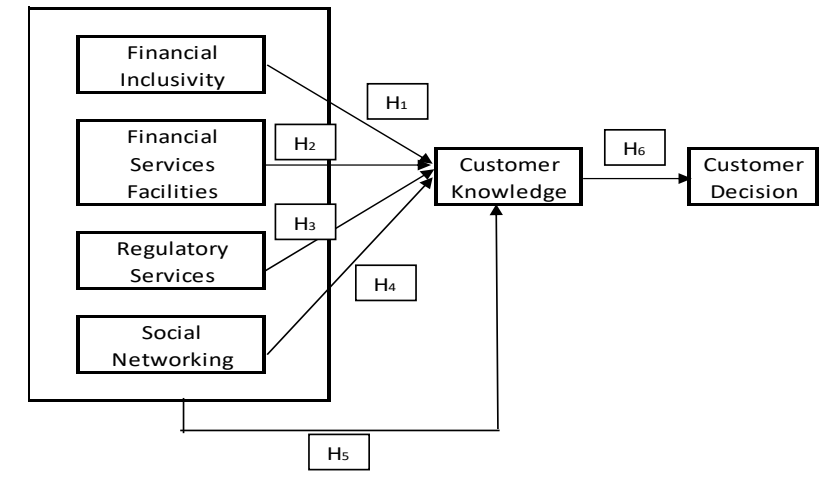

Fig. 1. Conceptual Framework

Based on the conceptual framework, the following hypotheses are proposed:

$\mathrm{H}_{1}$ : There is a positive relationship between the financial inclusivity and the customer knowledge.

$\mathrm{H}_{2}$ : There is a positive relationship between the financial service facilities and the customer knowledge.

$\mathrm{H}_{3}$ : There is a significant relationship between the regulatory services and the customer knowledge. 
$\mathrm{H}_{4}$ : There is a strong relationship between the social networking and the customer knowledge.

$\mathrm{H}_{5}$ : There is an effect from financial inclusivity, financial service facilities, regulatory services, and social networking technology to customer knowledge.

$\mathrm{H}_{6}$ : There is a significant relationship between customer knowledge and customer decision in choosing the P2P lending platform.

\section{Methodology}

This was descriptive research with a single cross-sectional data collection, since data collection was done once within the specific period of time (Malhotra, 2010). Nunnaly (1978) stated that the minimum sample that can be tested statistically is 30 . The research mainly focuses on the ultramicro segment markets located in Java Island. The targeted sample used was 1,000 respondents collected using stratified random sampling method to give the generalization of the population. These respondents are located in municipalities from 6 provinces in Java, with each province represented as follows: Banten province (160 respondents), East Java (166 respondents), Central Java (166 respondents), West Java (173 respondents), DKI Jakarta (168 respondents), and Yogyakarta (167 respondents). The respondents would choose the best answer provided in the questionnaire designed in the Likert scale. The questionnaire has two parts: the first part covered the demographics and characteristics of the respondents and the second part was related to the research questions. As a quantitative research, all primary data collected had been analyzed statistically using Algorithm PLS. Hypotheses developed in the conceptual framework were analyzed. Financial inclusivity variables were measured with some indicators, such as bank accessibility $\left(\mathrm{X}_{1}\right)$, financing distribution $\left(\mathrm{X}_{2}\right)$, financial transaction $\left(\mathrm{X}_{3}\right)$, and business profile $\left(\mathrm{X}_{4}\right)$ (Bank Indonesia Report, 2018). The variable of financial service facilities was measured by lending facilities $\left(\mathrm{X}_{5}\right)$ and relationship quality $\left(\mathrm{X}_{6}\right)$ (Michael, Falzon, \& Shamdasani, 2015). Regulatory services variables were indicated by customer protection $\left(\mathrm{X}_{7}\right)$ and industry protection $\left(\mathrm{X}_{8}\right)$ (Liu, Sidhu, Beacom, \& Valente, 2017). Social networking variables were explained by the technology/ICT usage $\left(\mathrm{X}_{9}\right)$ and group networking $\left(\mathrm{X}_{10}\right)$ (Perner, 2017). McDaniel and Gates (2015) stated that customer knowledge $\left(Z_{11}\right)$ was related to all the information received by customers. Finally, customer knowledge would be a critical basis in assisting customers in making appropriate decisions for P2P lending platforms ( $\left.\mathrm{Y}_{12}\right)$ (Khosravi, 2014).

\section{Empirical Results}

Demographic analysis showed the respondents' profile including characteristics and behavior. All respondents are rural bank customers, with $58 \%$ of them as existing customers for three to five years. One point to consider in choosing rural banks is its safety, since the government protects all financial transactions (38\%). The biggest transaction made (63\%) was in credit activities to develop businesses (73\%), with the maturity date between three and five years (47\%) and with the average nominal amount of one hundred up to five hundred million rupiahs $(22 \%)$. The main constraint when applying credit was the availability of assets (35\%), longer time for credit approval (28\%), and complex administration and documentation requirements $(21 \%)$. This research showed theoretical analysis for each dimension, which can be used in making managerial decisions. Tables 2 and 3 show results for both financial inclusivity and financial service facilities dimensions. The highest score for the financial inclusivity dimension was seen in bank accessibility. The customers' aim in applying credit in rural banks is business expansion. Fintech would shorten the settlement of the financial transaction, but it would not replace the existence of rural bank employees. Customers needed the assistance of employees in handling and giving solutions to their financial problems.

Table 2

Descriptive Analysis for Financial Inclusivity Dimension $(\mathrm{n}=1,000)$

\begin{tabular}{|c|c|c|}
\hline Code & Financial Inclusivity (FI) & Score \\
\hline \multicolumn{3}{|c|}{ Bank Accessibility $\left(X_{1}\right)$} \\
\hline FI 1 & I am a customer of Rural Bank in Indonesia & 18,680 \\
\hline FI 2 & $\begin{array}{l}\text { I always use banking services in doing my financial transactions (include the activities of saving, cash withdrawal, } \\
\text { payment, transfer and fund borrowing) }\end{array}$ & 15,320 \\
\hline FI 3 & I must fill the application form and complete all the supporting documents & 14,870 \\
\hline FI 4 & I must follow long and difficult process in doing my financial transactions & 12,110 \\
\hline \multicolumn{3}{|c|}{ Financing Distribution $\left(X_{2}\right)$} \\
\hline FI 5 & The rural bank has a strategic branch location & 9,880 \\
\hline FI 6 & The rural bank has flexible office hours & 9,002 \\
\hline \multicolumn{3}{|c|}{ Financial Transaction Accessibility $\left(X_{3}\right)$} \\
\hline FI 7 & I can borrow money from the rural bank easily & 12,870 \\
\hline FI 8 & I have to provide collateral if I apply the credit & 15,520 \\
\hline FI 9 & The rural bank will make an appraisal of my collateral & 12,230 \\
\hline FI 10 & The approved nominal credit is lower than the nominal amount of my collateral & 12,110 \\
\hline FI 11 & There will be long process in applying the credit & 14,890 \\
\hline \multicolumn{3}{|c|}{ Business Profile $\left(\mathrm{X}_{4}\right)$} \\
\hline FI 12 & I am doing the financial transaction for my personal interest. & 10,250 \\
\hline FI 13 & I always use banking services in running my business & 10,760 \\
\hline FI 14 & My business net sales is less than 200 million rupiahs per year & 9,870 \\
\hline \multirow[t]{3}{*}{ FI 15} & My employees are less than 50 persons & 15,620 \\
\hline & Total Score & 194,000 \\
\hline & Average & 12,930 \\
\hline
\end{tabular}


Source: SPSS Result (2019).

Table 3

Descriptive Analysis for Financial Service Facilities Dimension $(\mathrm{n}=1,000)$

\begin{tabular}{|c|c|c|}
\hline Code & $\begin{array}{c}\text { Financial Service Facilities (FS) } \\
\text { Lending Facilities }\left(X_{5}\right)\end{array}$ & Score \\
\hline FS 1 & I always borrow money from the bank to expand my business & 18,680 \\
\hline FS 2 & My payment term is less than 1 year & 15,320 \\
\hline FS 3 & I have to pay higher interest rate for my credit & 14,870 \\
\hline FS 4 & $\begin{array}{r}\text { I can borrow more than } 2 \text { billion rupiahs as long as I have collateral } \\
\text { Relationship Quality }\left(\boldsymbol{X}_{\boldsymbol{6}}\right)\end{array}$ & 12,110 \\
\hline FS 5 & I need adequate information before doing my financial transaction & 9,880 \\
\hline FS 6 & I always need staff support in doing my financial transaction & 9,020 \\
\hline & $\begin{array}{l}\text { Total Score } \\
\text { Average }\end{array}$ & $\begin{array}{l}79,880 \\
13,310\end{array}$ \\
\hline
\end{tabular}

Source: SPSS Result (2019).

Meanwhile, the government had to set the maximum limit of interest rates to protect both customers and financial industries, as shown in Table 4.

Table 4

Descriptive Analysis for Regulatory Service $(\mathrm{n}=1,000)$

\begin{tabular}{|c|c|c|}
\hline Code & $\begin{array}{l}\text { Regulatory Services }(R S) \\
\text { Customer Protection }\left(X_{7}\right)\end{array}$ & Score \\
\hline RS 1 & I feel secured when I borrow money from the Bank & 19,800 \\
\hline RS 2 & I know that the government make a clear regulation to protect the customer & 16,600 \\
\hline RS 3 & The financial digital platform is not regulated clearly by the government & 19,400 \\
\hline \multicolumn{3}{|c|}{ Industry Protection $\left(X_{8}\right)$} \\
\hline RS 5 & There must be a government regulation to control the financial digital protection & 20,100 \\
\hline RS 6 & The government must set maximum limit of interest rate & 24,300 \\
\hline RS 7 & The government must set maximum nominal amount of credit & 22,180 \\
\hline RS 8 & The government must set minimum financial competence for human resources qualification & 19,850 \\
\hline RS 9 & The government must set tight regulation in verifying the approved credit application & 23,180 \\
\hline \multicolumn{2}{|r|}{ Total Score } & 185,170 \\
\hline \multicolumn{2}{|r|}{ Average } & 20,570 \\
\hline
\end{tabular}

Source: SPSS Result (2019).

Table 5 shows results for the social networking dimension. Customers were very familiar in using digital technology devices including mobile phones and the internet in doing their financial transactions such as bill payments or transfers. Membership in the social media community had strong influence in building trust in using fintech.

Table 5

Descriptive Analysis for Social Networking $(\mathrm{n}=1,000)$

\begin{tabular}{|c|c|c|}
\hline Code & $\begin{array}{l}\text { Social Networking }(\mathrm{SN}) \\
\text { Technology/ICT Usage }\left(\mathrm{X}_{9}\right)\end{array}$ & Score \\
\hline SN 1 & I am using electronic devices in doing my financial transactions & 24,800 \\
\hline $\mathrm{SN} 2$ & I am having difficulties in using my digital financial transactions & 23,320 \\
\hline SN 3 & Only limited transaction can be accessed using electronic banking & 19,150 \\
\hline SN 4 & $\begin{array}{c}\text { The frequency of my electronic banking transaction is more than } 10 \text { times a month } \\
\text { Group Networking }\left(\boldsymbol{X}_{10}\right)\end{array}$ & 20,250 \\
\hline SN 5 & I am joining social media group & 13,750 \\
\hline SN 6 & I always communicate with other members of the group & 14,900 \\
\hline SN 7 & I am doing online business frequently & 12,180 \\
\hline & $\begin{array}{l}\text { Total Score } \\
\text { Average }\end{array}$ & $\begin{array}{c}128,350 \\
18,340\end{array}$ \\
\hline
\end{tabular}

Source: SPSS Result (2019).

Table 6

Descriptive Analysis for Customer Knowledge $(\mathrm{n}=\mathbf{1 , 0 0 0})$

\begin{tabular}{lll}
\hline Code & \multicolumn{1}{c}{$\begin{array}{c}\text { Customer Knowledge }(\text { CK }) \\
\text { Customer Knowledge }\left(\boldsymbol{Z}_{11}\right)\end{array}$} \\
\hline CK 1 & I know there's an electronic platform providing the credit & 33,680 \\
CK 2 & Credit online process is speedy and simple & 34,420 \\
CK 3 & Credit online doesn't request any collateral & 28,760 \\
CK 4 & Credit online is charging high interest rate & 32,200 \\
CK 5 & Credit online is limited in short-term repayment (less than a year) & 30,060 \\
CK 6 & Maximum nominal amount for credit online without collateral is 500 million rupiah \\
CK 7 & I am applying credit online to expand my business & Total Score \\
& & Average \\
\hline
\end{tabular}


Knowledge of fintech characteristics would assist customers in making decisions with regard to the appropriate service to use. They know that fintech offers simple and easier procedures for credit application. While the services offered limited credit nominal and shorter maturity date, these services did not ask for any asset as collateral. Therefore, they had to pay for a higher interest rate. Understanding the benefits, risks, and weaknesses of the fintech system would allow them to make sound decisions in borrowing funds from P2P providers, as shown in Table 6 and Table 7.

Table 7

Descriptive Analysis for Customer Decision $(\mathrm{n}=1,000)$

\begin{tabular}{ccc}
\hline Code & Customer Decision $(\boldsymbol{C D})$ & Score \\
\hline & Customer Decision $\left(\boldsymbol{Y}_{12}\right)$ & \\
CD 1 & I am interested in borrowing the money using digital platform & 9,650 \\
C2 2 & I prefer to borrow the money online using digital platform than from the conventional bank & Total Score \\
& Average & $\mathbf{1 8 , 4 5 0}$ \\
& $\mathbf{9 , 2 3 0}$ & \\
\hline
\end{tabular}

Source: SPSS Result (2019).

The Cronbach's alpha test was done to check the reliability of the research questions. It was designed to accurately measure all the variables used in this research (Hair, 2013). A minimum score of 0.700 would explain a strong internal consistency and high reliability of the research indicators (Hair, 2015). With a minimum score of 0.500 , the average variance extraction (AVE) would give better discriminant validity (Park \& Mercado, 2015). Table 8 shows that all dimensions used in this research were highly correlated and had high internal consistency. The dimensions recorded a Cronbach's alpha score of more than 0.700 , with the highest score (0.911) seen for the customer decision dimension. In addition, the AVE score for each dimension is more than 0.500 , with the customer decision dimension receiving the highest score $(0.915)$. On the other hand, financial inclusivity had the smallest score for both Cronbach's alpha and AVE (0.718 and 0.546, respectively).

Table 8

Validity and Reliability Constructs

\begin{tabular}{lcccc}
\multicolumn{1}{c}{ Constructs } & Cronbach's Alpha & rho_A & Composite Reliability & Average Variance Extraction \\
\hline Customer Decision (CD) & 0.911 & 1.017 & 0.956 & 0.898 \\
Customer Knowledge (CK) & 0.865 & 0.882 & 0.915 \\
Financial Inclusivity (FI) & 0.718 & 0.788 & 0.824 & 0.598 \\
Financial Service Facilities (FSF) & 0.761 & 0.818 & 0.891 & 0.603 \\
Regulatory Services (RS) & 0.882 & 0.898 & 0.927 & 0.695 \\
Social Networking (SN) & 0.893 & 0.929 & 0.915 \\
\hline
\end{tabular}

Source: SPSS Result (2019).

Statistical collinearity presented in Table 9 would explain the positive and strong relationship between each variable. Hair (2013) stated that the minimum score of collinearity was 0.900 . Each independent variable in this research had a strong relationship with both intervening and dependent variables. Social networking had the strongest collinearity with customer knowledge (with a score of 1.886), whereas financial inclusivity had the weakest collinearity with customer knowledge (a score of 1.331). Other two independent variables, namely regulatory services and financial service facilities, had scores of 1.851 and 1.765 , respectively. Meanwhile, customer knowledge had a positive collinearity with the customer decision variable $($ score $=1.000)$. Scores higher than 0.900 could mean multicollinearity among the variables.

Table 9

Statistical Collinearity

\begin{tabular}{lrrr}
\hline & CD & CK & FI \\
\hline Customer Knowledge (CK) & 1.000 & & \\
Financial Inclusivity (FI) & & 1.331 & 1.000 \\
Financial Service Facilities (FSF) & & 1.765 & \\
Regulatory Services (RS) & 1.851 & 1.000 \\
Social Networking (SN) & 1.886 & 1.000 \\
\hline
\end{tabular}

Source: SPSS Result (2019).

Table 10

R-Square

\begin{tabular}{lcc}
\hline & R Square & Adjusted R Square \\
\hline Customer Decision & 0.040 & 0.031 \\
Customer Knowledge & 0.687 & 0.532 \\
Financial Inclusivity & 0.005 & 0.256 \\
Financial Service Facilities & 0.237 & 0.334 \\
Regulatory Services & 0.369 & 0.418 \\
Social Networking & 0.462 & 0.454 \\
\hline
\end{tabular}

Source: Data Analysis using LISREL 8.80.

The statistical calculation of R-square was used to determine the coefficient and interrelation of the variables (Hair, 2013). R-square measures the degree in which the independent variables (financial inclusivity, financial service facilities, regulatory services, and social networking) explain the customer knowledge and customer decision variables. Customer knowledge had 
the highest score $(0.687)$ as seen in Table 10 , which means that $68.7 \%$ of customer decision was influenced by the customer knowledge variable. Meanwhile, the customer knowledge itself was determined by social networking (46.2\%). Table 11 shows the important role of the intervening variable, customer knowledge. Financial inclusivity, financial service facilities, regulatory services, and social networking variables did not have any direct effect to customer decisions.

Table 11

Indirect Effect

\begin{tabular}{|c|c|c|c|c|c|}
\hline & CD & CK & FSF & RS & SN \\
\hline CK & & & & & -0.036 \\
\hline FI & -0.015 & -0.014 & & & \\
\hline FSF & -0.040 & 0.289 & & & \\
\hline RS & -0.077 & 0.051 & -0.048 & & -0.024 \\
\hline $\mathrm{SN}$ & -0.117 & & & & \\
\hline
\end{tabular}

Source: Data Analysis using LISREL 8.80.

Table 12 presents the path coefficient of all variables. Social networking had a t-value score of 6.692, the highest among variables with an effect on customer knowledge. This is followed by the regulatory services (2.836), financial services ( 0.853$)$, and financial inclusivity (0.691).

Table 12

Path Coefficient

\begin{tabular}{lccc}
\hline & Sample Mean & Standard Deviation & t-Values \\
\hline CK $\rightarrow$ CD & -0.025 & 0.090 & 2.233 \\
FI $\rightarrow$ CK & 0.102 & 0.103 & 0.691 \\
FI $\rightarrow$ FS & -0.080 & 0.086 & 0.026 \\
FS $\rightarrow$ CK & -0.103 & 0.109 & 0.490 \\
FS $\rightarrow$ SN & 0.503 & 0.073 & 0.406 \\
RS $\rightarrow$ CK & 0.336 & 0.117 & 0.853 \\
RS $\rightarrow$ FI & 0.692 & 0.078 & 6.820 \\
SN $\rightarrow$ CK & 0.587 & 0.087 & 2.836 \\
\hline Source: Data Analysis using LISREL 8.80 & & 0.000 \\
\hline
\end{tabular}

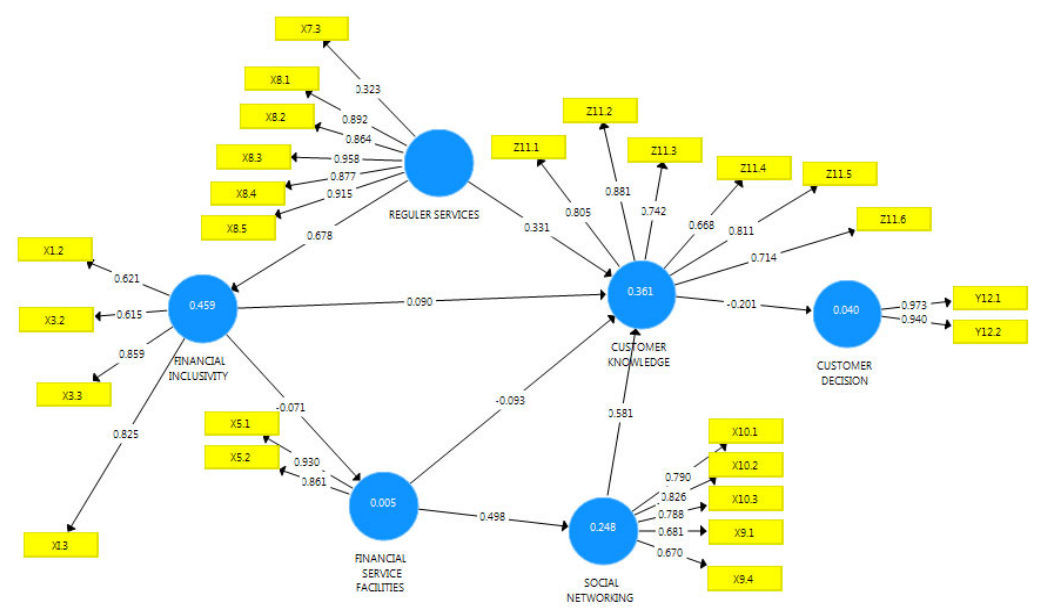

Source: Data Analysis using LISREL 8.80.

Fig. 2. Algorithm PLS

Data from Table 12 (path coefficient), Fig. 2 (algorithm PLS), and Fig. 3 (bootstrapping) explained the hypothesis testing seen in Table 13.

Table 13

The Result of Hypothesis Testing

\begin{tabular}{|c|c|c|c|c|}
\hline Hypotheses & Variables & Coefficient Standard & t-Value & Statistical Conclusion \\
\hline $\mathrm{H}_{1}$ & $\mathrm{FI} \rightarrow \mathrm{CK}$ & 0.090 & 0.691 & Data Supported \\
\hline $\mathbf{H}_{2}$ & $\mathrm{FSF} \rightarrow \mathrm{CK}$ & -0.093 & 0.853 & Data Supported \\
\hline $\mathbf{H}_{3}$ & $\mathrm{RS} \rightarrow \mathrm{CK}$ & 0.331 & 2.836 & Data Supported \\
\hline $\mathbf{H}_{4}$ & $\mathrm{SN} \rightarrow \mathrm{CK}$ & 0.581 & 5.692 & Data Supported \\
\hline $\mathbf{H}_{5}$ & FI, FSF, RS and SN $\rightarrow$ CK & 0.709 & 9.972 & Data Supported \\
\hline $\mathbf{H}_{6}$ & $\mathrm{CK} \rightarrow \mathrm{CD}$ & -0.201 & 2.233 & Data Supported \\
\hline
\end{tabular}




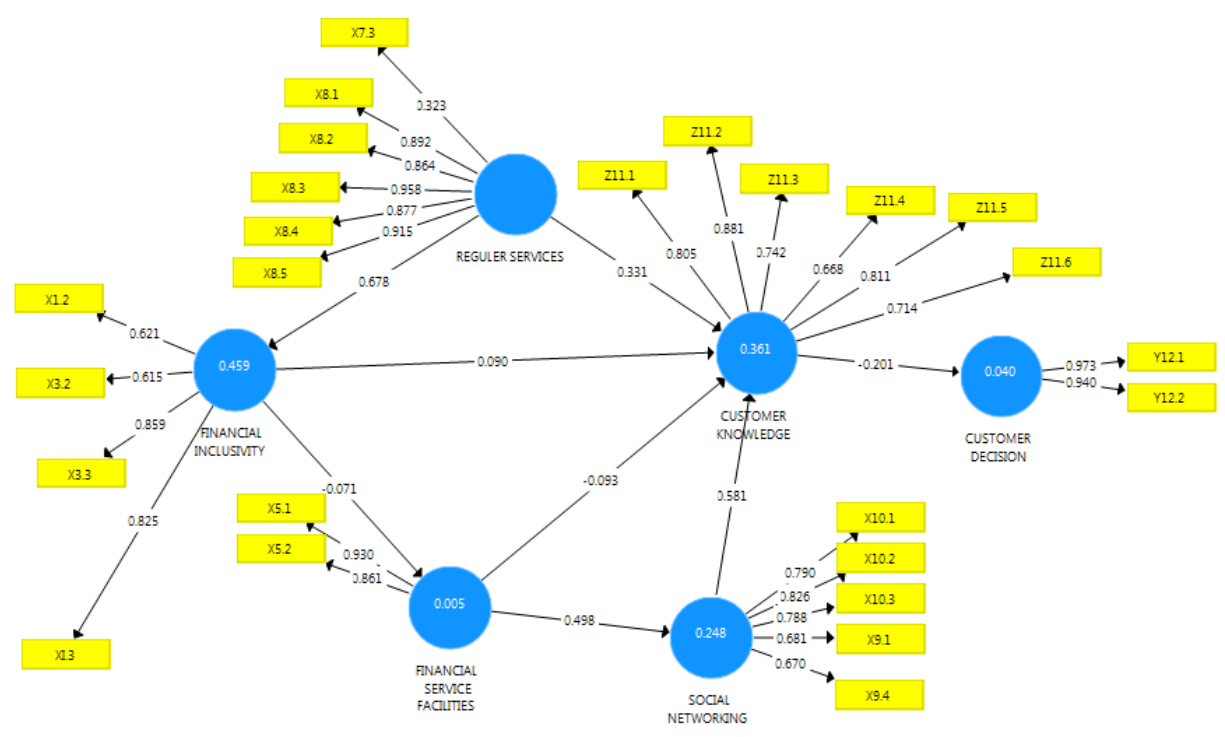

Source: Data Analysis using LISREL 8.80

Fig. 3. Bootstrapping

Results from the research and testing the hypotheses showed that in digital technology, social networking has the greatest influence in customer knowledge. Membership in groups in social networks exerts influence through mutual exchange of information. With the growth of digital technology, social media can be accessed easily. Customers tend to immediately trust the information obtained from a member of their group. This finding was in line with the previous research conducted by Aisenberg et al. (2016) who stated that social media is a source and center of knowledge transmission. It is an interactive media where information is transmitted and communication between members of groups occurs. This research also supported data from the World Bank Report (2018) that showed the majority of Indonesians borrowed money from families and friends.

In addition, customer knowledge about fintech was influenced by the presence and clarity of government rules and regulation governing the fintech business. Government regulations could reduce uncertainty and risks related with failures in the fintech business. Regulations provide guarantee and protection for customers in terms of financial procedures, such as interest rate, administrative procedures, and default settlement. The findings were in line with previous research stating that transparency and continuous regulation must be conducted to support the sustainability of banking business, since each country had different cultures that would reflect into the characteristics of the purchase behavior (Egbunike et al., 2018). This study revealed the following limitations of the fintech system: the small nominal amount of the loan and the short loan duration. Meanwhile, the primary reason why customers needed the loan was to expand their business activities. All the independent variables (financial inclusivity, financial service facilities, regulatory services, and social networking) simultaneously had the most significant effect to customer knowledge toward the fintech business. The existence and completeness of the fintech information would affect customer decisions in using fintech as an alternative solution in seeking business loans. This research would give another perspective in increasing the penetration of fintech business in the Indonesian market and, at the same time, strengthening the financial inclusivity for SMEs to borrow loans for their businesses. Since fintech is likely seen as an alternative source of financing using information technology, an increase in participation of all variables in the fintech ecosystem, including the government, financial industries, and banking institutions related with the regulation and protection aspects, is necessary. There is also a need to encourage active participation in educating the community with the advantage of fintech business in doing financial transactions.

\section{Acknowledgments}

The author would like to thank Direktorat Riset dan Pengabdian Masyarakat, Direktorat Jendral Penguatan Riset dan Pengembangan dan Kementerian Riset, Teknologi dan Pendidikan Tinggi according to Research Contract Number: 1626/HD/LPPM$\mathrm{UMN} / \mathrm{III} / 2020$ for providing financial support for this research.

\section{References}

Accenture (2016). Global FinTech investment growth continues in 2016 driven by Europe and Asia. Accenture Study. Aisenberg, F.H., Durst, S., \& Hesamamiri, R. (2016). The impact of social media on knowledge management. In 11th International Forum on Knowledge Asset Dynamics (IFKAD)-Dresden, 15-17 June 2016. 
Anothai, N. \& Beise-Zee, R. (2014). Customer preference for decision authority in credence services: The moderating effects of source credibility and persuasion knowledge. Managing Service Quality, 24(3), 274-299.

Bank Indonesia FinTech Office (2017). Ekonomi digital dan kebijakan moneter pemerintah. Bank Indonesia Publishing.

Bank Indonesia Report (2018). Analisa perkembangan finansial dan perbankan di Indonesia di tahun 2018. Bank Indonesia Publishing.

Blohm, I., Leimeister, J. M. \& Kremar, H. (2013): Crowdsourcing: How to Benefit from (Too) Many Great Ideas. MIS Quarterly Executive, 4(12), 199-211.

Egbunike, F.C., Emudainohwo, O.B., Gunardi, A., Kurniasari, F., Prihanto, J.J.N. (2018). Sustainaibility Accounting Practices and Disclosure by Multinational Corporation in Nigeria. Journal of Applied Economic Sciences, 13(3), 751-759.

Diemers, D., Lamaa, A., Salamat, J. \& Steffens, T. (2015). Developing a FinTech ecosystem in the GCC Strategy. PWC Publishing.

Gaur, S.S., Xu, Y., Quazi, A. \& Nandi, S. (2011), Relational impact of service providers' interaction behavior in healthcare. Managing Service Quality, 21(1), 67-87.

Hair, J.F. (2013). Multivariate Data Analysis ( $7^{\text {th }}$ Ed.). Pearson Education Limited.

Hartman, A., Kador, J., \& Sifonis, J. G. (2001). Net Ready: Strategies for Success in the Economy. McGraw-Hill, Inc.

Herdiawan (2017). Kebijakan Moneter Bank Indonesia Dalam Mengantisipasi Ekonomi Digital. Bank Indonesia Report.

Holland FinTech. (2015). The future of finance: The socialization of finance. Holland Publishing.

IBRD/The World Bank. The little data book on financial inclusion (2018). The World Bank Publishing.

Kementerian Informasi dan Komunikasi (2018). Peta kebijakan pemerintah di bidang teknologi informasi. KemInfokom Press.

Khodakarami, F. \& Chan, Y.E. (2014). Exploring the role of customer relationship management (CRM) systems in customer knowledge creation. Information \& Management, 51(1), 27-42.

Khosravi, A. (2014). A Review of Customer Knowledge Management Importance. Journal of Soft Computing and Decision Support Systems, 1(1), 45-52.

Kuppuswamy, V., \& Bayus, B. L. (2013). Crowdfunding creative ideas: The dynamics of projects backers in Kickstarter: Ssrn working paper.

Kurniasari, F., Jusuf, E., \& Gunardi, A. (2018). The readiness of Indonesian toward MOOC system. International Journal of Engineering and Technology, 7(3), 1631-36.

Lee, I., \& Shin, Y. J. (2018). Fintech: Ecosystem, business models, investment decisions, and challenges. Business Horizons, $61(1), 35-46$.

Liu, W., Sidhu, A., Beacom, A. \& Valente, T.W (2017). Social Network Theory: The International Encyclopedia of Media Effects. JohnWiley \& Sons, Inc.

Malhotra (2010). Marketing Research. $4^{\text {th }}$ ed., Pearson Education.

McDaniel Jr, C., \& Gates, R. (2018). Marketing research. John Wiley \& Sons.

Michael, B., Falzon, J., \& Shamdasani, A. (2015). A Theory of Financial Services Competition, Compliance and Regulation. University of Hong Kong, Faculty of Law Research Paper No. 2015/001.

Nanda, K., \& Kaur, M. (2016). Financial inclusion and human development: a cross-country evidence. Management and Labor Studies, 41(2), 127-153.

Nguyen, H., \& Harrison, N. (2018). Leveraging customer knowledge to enhance process innovation: moderating effects from market dynamics, Business Process Management Journal, 25(2), 307-322. https://doi.org/10.1108/BPMJ-032017-0076.

Nunnaly, J. (1978). Psychometric Theory. New York: McGraw-Hill.

OECD (2015). New Approaches to SME and Entrepreneurship Financing: Broadening the Range of Instruments, OECD Publishing, Paris.

OECD (2017). Digital Economy Outlook 2017, OECD Publishing, Paris.

Park, C.Y. \& Mercardo, R.V. (2015). Financial inclusion, poverty and income inequality in developing Asia. ADB Publishing.

Perner, L. (2017). Consumer Behavior: The Psychology of Marketing. Journal of Marshall School of Business. University of Southern California.

Reuters. (2016). Singapore to update electronic payment regulations in FinTech drive. Yahoo News.

Salomann, H., Dous, M., Kolbe, L. \& Brenner, W. (2005), Rejuvenating customer management: how to make knowledge for, from and about customers' work, European Management Journal, 23(4), 392-403.

Tai, Y.M., \& Ho, C.F. (2010). Effects of information sharing on customer relationship intention, Industrial Management \& Data Systems, 110(9), 1385-1401.

Tseng, S.-M., \& Wu, P.-H. (2014). The impact of customer knowledge and customer relationship management on service quality. International Journal of Quality and Service Sciences, 6(1), 77-96.

Uddin, M. R., Lopa, N. Z., \& Oheduzzaman, M. (2014). Factors affecting customers' buying decisions of mobile phone: a study on Khulna City, Bangladesh. International Journal of Managing Value and Supply Chains, 5(2), 21.

Walchek, S. (2015). The unbundling of finance. Tech-Crunch.

Williams-Grut, O. (2016). Deloitte just trashed the hype around a \$180 billion FinTech market. Business Insider.

World Bank Report (2018). Developing Countries Economic Overlook (Indonesia). World Bank.

Yang, S. (2015). Why Wall Street is pouring money into companies that want to eat its lunch. Business Insider.

Zhu, R., Dholakia, U. M., Chen, X., \& Algesheimer, R. (2012). Does online community participation foster risky financial behavior? Journal of Marketing Research, 49(3), 394- 407. 
Zvilichovsky, D., Inbar, Y., \& Barzilay, O. (2015). Playing both sides of the market: Success and reciprocity on crowdfunding platforms. Available at SSRN 2304101.

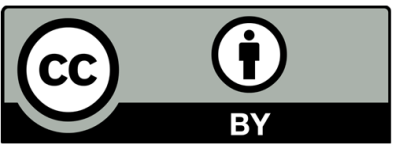

(C) 2021 by the authors; licensee Growing Science, Canada. This is an open access article distributed under the terms and conditions of the Creative Commons Attribution (CC-BY) license (http://creativecommons.org/licenses/by/4.0/). 